\title{
The Vegetation of Saskatchewan
}

\author{
By August J. Breitung
}

Two major units of vegetation cover the Saskatchewan landscape, viz: (A) the forest formation, occupying the northern two-thirds and (B) grassland, covering the southern third of the area (Fig. 1). Each formation is the product of climate and controlled by it. The forest formation may be subdivided into seven natural forest sections, based on broad uniformity of association, which is the result of topography, soil, bedrock, and local climate. Following is a list of the forest sections represented, the associated species are given in the order of their importance: (1) Northern Transition Section (open forest tundra)-black spruce (Picea mariana), tamrack (Larix laricina), white spruce (Picca glauca), jack pine (Pinus Banksiana) (2) Northern Coniferous Section-black spruce (Picea mariana), white spruce (Picea glauca) tamrack (Larix laricina), jack pine (Pinus Banksiana), aspen (Populus tremuloides), balsam poplar (Populus balsmanifera), Alaska birch (Betula resinifera), (3) Manitoba Lowlands Section-black spruce (Picea mariana), white spruce (Picea glauca), tamrack (Larix laricina), balsam poplar (Populus balsamifera), paper birch (Betula papyrifera), (4) Mixed Wood Section-white spruce (Picea glauca), aspen (Populus tremuloides), balsam poplar (Populus balsamifera), paper birch (Betula papyrifera), black spruce (Picea mariana), tamrack (Larix laricina), jack pine (Pinus Banksiana), balsam fir (Abies balsamea), (5) Aspen Grove Section (park belt)-aspen (Populus tremuloides), balsam poplar (Populus balsamifera) with Manitoba maple (Acer Negundo, var. interius) and green ash (Fraximus pennsylvanica, var. lanceolata) in river valleys, (6) Aspen-Oak Section-aspen (Populus tremuloides), bur oak (Quercus macrocarpa), green ash (Fraxinus pennsylvanica, var. lanceolata), Manitcba maple (Acer Negundo, var. interius), American Elm (Ulmus americana), and (7) Foothills Section-Lodgepole pine (Pinus contorta, var. latifolia), Alberta white spruce (Picea glauca, var. albertiana), and aspen (Populus tremuloides).

Within the grassland formation, students recognize the following seven communities: (1) Stipa-Bouteloua, (2) Boutelous-Stipa, (3) Stipa-Agropyron, (4) Agropyron-Muhlenbergia, (5) Agropyron-Koeleria, (6) Bouteloua-Agropyron fasciations, and (7) an Agropyron Smithii consocies. A detailed description of the grassland formation is given in "Ecology of the Mixed Prairie in Canada" by R. T. Coupland, Ecological Monographs, 20: 271-315, 1950.

Certain plant species are peculiar to the grassland formation, others to the forest. Aquatic species are usually distributed throughout the entire area and do not correspond with any plant formation. A number of closely related eastern and western species meet or overlap in the area, for example: the eastern Salix humilis and the western S. Scouleriana; the eastern S. lucida and the western $S$. lasiandra. Other species are circumboreal in distribution, such as: field horsetail (Equisetum arvense), cat-tail (Typha latifolia), grassy-leaved pondweed (Potomogeton gramineus), marsh blue-grass (Poa palustris), hoary sedge (Carex canescens), hooded ladies' tresses (Spiranthes Romanzoffiana), marsh cinquefoil (Potentilla palustris), fireweed (Epilobium angustifolium), red bearberry (Arctostaphyllos Uva-ursi), yellow rattle (Rhinanthus Crista-Gallii), butterwort (Pinguicula vulgaris), northern bedstraw (Galium boreale), and tall white fleabane (Erigeron acre).

With increasing present day knowledge in taxonomy and phytogeography, the flora of Saskatchewan is becoming better known. 